OPEN ACCESS

Edited by:

Min Wang,

China University of Petroleum

(Huadong), China

Reviewed by:

Gang Gao,

China University of Petroleum, China

Bo Liu,

Northeast Petroleum University, China

*Correspondence:

Weihao La

1332254719@qq.com

Specialty section:

This article was submitted to

Economic Geology,

a section of the journal

Frontiers in Earth Science

Received: 03 July 2021

Accepted: 09 August 2021

Published: 29 September 2021

Citation:

Wang W, La W, Fan T, Xu X, Liu Y and Lv Q (2021) A Comparative Study on Microscopic Characteristics of

Volcanic Reservoirs in the Carboniferous Kalagang and Haerjiawu Formations in the

Santanghu Basin, China.

Front. Earth Sci. 9:735703.

doi: 10.3389/feart.2021.735703

\section{A Comparative Study on Microscopic Characteristics of Volcanic Reservoirs in the Carboniferous Kalagang and Haerjiawu Formations in the Santanghu Basin, China}

\author{
Weiming Wang ${ }^{1}$, Weihao $\mathrm{La}^{1 *}$, Tanguang Fan ${ }^{2}$, Xiongfei $\mathrm{Xu}^{2}$, Yingnan $\mathrm{Liu}^{1}$ and Qixia $\mathrm{Lv}^{1}$ \\ ${ }^{1}$ School of Earth Science and Technology, China University of Petroleum (East China), Qingdao, China, ${ }^{2}$ Research Institute of \\ Exploration and Development, PetroChina Tuha Oilfield Company, Hami, China
}

Self-jetting high-yield oil flow was obtained from Ma 67 and Ma 36 wells drilled in the volcanic reservoirs of the Haerjiawu Formation in the Santanghu Basin, China. This has shifted the prospectors' attention to the Haerjiawu Formation from the Kalagang Formation, which is generally considered to have favorable physical properties. To further explain the geological reasons why oil flow can jet itself from the volcanic rocks in the Haerjiawu Formation with poor physical properties, this study carries out a systematic comparison on the microscopic pore structures of volcanic rocks through unconventional tests such as low-temperature nitrogen adsorption, high-pressure mercury injection, and constant-rate mercury injection based on the analyses of physical properties and minerals. The results obtained are as follows. The volcanic rocks of the Kalagang Formation have relatively high pore permeability. However, their micropores have a wide distribution range of pore size and feature highly meandering structures and strong heterogeneity. Meanwhile, small pore throats connect large pores in the volcanic rocks, resulting in a relatively high pore/throat ratio. All these are conducive to the occurrence of tight oil and gas but unfavorable for the flow of oil and gas. The volcanic rocks in the Haerjiawu Formation have relatively low volcanic permeability. However, small pores connect large pore throats in the volcanic rocks; thus, leading to a relatively low pore/throat ratio. Meanwhile, the volcanic rocks feature low meandering structures, strong homogeneity, and high connectivity. All these are favorable for the formation of tight oil and gas reservoirs. These assessment results also indicate that the assessment indices of tight volcanic reservoirs should not only include porosity and permeability. Instead, more attention should be paid to the microscopic pore structures, and it is necessary to analyze the charging and flow of tight oil from the configuration of pores and pore throats. This study not only explains the geological factors of the wells with selfjetting high-yield oil flow in the Haerjiawu Formation from the perspective of microscopic pore structures but also provides a new idea and comparison method for the assessment of tight reservoirs in other areas.

Keywords: Santanghu basin, Kalagang formation, Haerjiawu formation, micropore structure, pore/throat configuration, volcanic rock 


\section{INTRODUCTION}

The Santanghu Basin is located in the northeast of Xinjiang Uygur autonomous region, China, and lies in the part where the Siberia and Kazakhstan plates converge. Carboniferous strata are widely developed in the basin, with hugely thick source rocks of marine-continental transitional facies deposited and hugely thick volcanic rocks built, thus forming independent petroliferous associations (Li et al., 2010; Wang et al., 2010; Liu et al., 2013; Tian et al., 2019). With an increase in the attention to oil and gas exploration of volcanic rocks, many oil and gas reservoirs have been discovered in the Malang Sag of the Santanghu Basin (Ma et al., 2017; Su et al., 2020; Yang et al., 2019; Liu, Bechtel, Sachsenhofer). In particular, oil and gas manifestations were discovered in 23 layers (height: about $294 \mathrm{~m}$ ) in the Kalagang Formation during the drilling of Well Niudong 110 that was deployed in the southern wing of the Niudong structure in the Malang Sag in 2015, with the highest daily oil production of $21.08 \mathrm{~m}^{3}$. This opened the exploration of the tight oil in Carboniferous volcanic rocks in the Santanghu Basin. Owing to the intense exploration of volcanic oil and gas reservoirs, the corresponding exploration technologies and theoretical understanding have also been rapidly improved. (Hou et al., 2011; Huang et al., 2012). However, the exploration of the volcanic rocks in the Santanghu Basin suffers a late start and a low level. As a result, much geological understanding of the volcanic rocks is still at the exploratory stage overall, and most especially the pore structures in the volcanic reservoirs are yet to be ascertained. Previous researchers compared and assessed the Carboniferous volcanic reservoirs using conventional test analysis methods such as casting thin section, core observation, conventional mercury injection, and porosity and permeability analysis. Accordingly, they generally believed that the volcanic rocks in the Kalagang Formation should be the focus of Carboniferous exploration due to their relatively high porosity and permeability. However, self-jetting high-yield oil flow with the highest daily oil production of $65.60 \mathrm{~m}^{3}$ was discovered in the Haerjiawu Formation in Ma 67 well in the Malang Sag later. This confirms that the Haerjiawu Formation with poor physical properties also has great development potential. Then some geological questions have been raised, such as why high-yield spontaneous oil flow was obtained from the volcanic rocks in the Haerjiawu Formation with low physical properties and whether the phenomenon of self-jetting oil flow indicates that the tight oil in the Haerjiawu Formation has better mobility. To answer these questions, it is necessary to start with the research on the refined microscopic pore structure of the reservoirs. Therefore, based on various high-precision methods such as HPMI, CRMI, and LTNA tests, this study compares and analyzes the differences in the microscopic pore structures in the target layers of the Kalagang and Haerjiawu formations and reasonably explains the difference in enrichment conditions of tight oil between the two formations, thus providing a basis for further exploration.

\section{SAMPLES AND EXPERIMENTS}

\section{Geological Background}

The Santanghu Basin is adjacent to the Junggar and Tuha basins in the southwest across Dahei and Barkol mountains and borders
Mongolia in the northeast. It lies between the Altai and Tianshan mountains and is distributed in the form of a long strip in the NW-SE trending, with a length of about $500 \mathrm{~km}$, a width of $40-70 \mathrm{~km}$, and an area of $2.3 \times 10^{4} \mathrm{~km}^{2}$. Therefore, it is a long and narrow intermountain superimposed basin. The first-order tectonic units in the basin are present in an NW-trending macroscopic pattern of two uplifts sandwiching one depression (i.e., the northeastern thrust uplift zone, the southwestern thrust nappe uplift belt, and the central depression zone). Among them, the central depression zone can be divided into four convex and five concave tectonic units (Figure 1), each of which is long and narrow in the south-north direction and is convex in the south and gentle in the north in terms of strata (Hou et al., 2011; Liu, Bechtel, Sachsenhofer). The central depression zone serves as the major oil and gas accumulation area, and most of the oil and gas discovered so far are concentrated in the Malang Sag in the central depression zone. The main Carboniferous target layers in the Malang Sag include the Kalagang and Haerjiawu formations. Among them, the Kalagang Formation is dominated by onshore eruption-overflow facies, with amygdaloidal lava developing and multiple-stage eruptive discontinuities visible inside. Therefore, weathered and leached volcanic reservoirs have developed inside. In terms of lithology, these reservoirs mainly include amygdaloidal basalts and autoclastic brecciated basalts, followed by autoclastic brecciated andesite and amygdaloidal andesite. Among them, the amygdala is mostly unfilled and semi-filled or shows corrosion characteristics (Liang et al., 2011; Liu et al., 2015). The Kalagang Formation is mainly distributed on the southwestern edge of the Malang Sag. It grows thinner from west to east and pinches out on the Fangliang Salient, with a regional thickness of 540-1,600 m. The Haerjiawu Formation is dominated by dotted central volcanic eruptions. In terms of lithology, it mainly includes the interbeds consisting of volcaniclastic sedimentary rocks, pyroclastic rocks, and volcanic lava, interbedded with carbonaceous mudstones, tuffaceous mudstones, and marls as a whole. The Haerjiawu Formation is widely distributed. It is thick in the southwestern, southeastern, and north-central parts of the Santanghu Basin, with a general residual thickness of 400-1,451 m.

\section{Tests and Analyses}

To accurately characterize the microscopic pores in the Carboniferous volcanic reservoirs in the Malang Sag of the Basinhu Basin, targeted LTNA (JiaChengzao and Li, 2012; Yu, 2013; Yang et al., 2013a; Hadlari, 2015; Chen et al., 2015; Liu, Gao, Liu; Liu, Sun, Zhang), CRMI, and HPMI tests were carried out on samples based on the analyses of porosity, permeability, X-ray diffraction, and scanning electron microscopy in this study. All the samples were regular column samples (about $2.5 \mathrm{~cm}$ in diameter). They were washed to remove oil and dried before tests. LTNA tests were conducted using a BSD-PS-series automatic specific surface area and porosity analyzer, and the steps are as follows. First, the samples were degassed at a high temperature of $150^{\circ} \mathrm{C}$ for $3 \mathrm{~h}$. Then the isotherm adsorption-desorption curves of the samples were obtained by the static volume method at an absolute temperature of $77 \mathrm{~K}$. The 


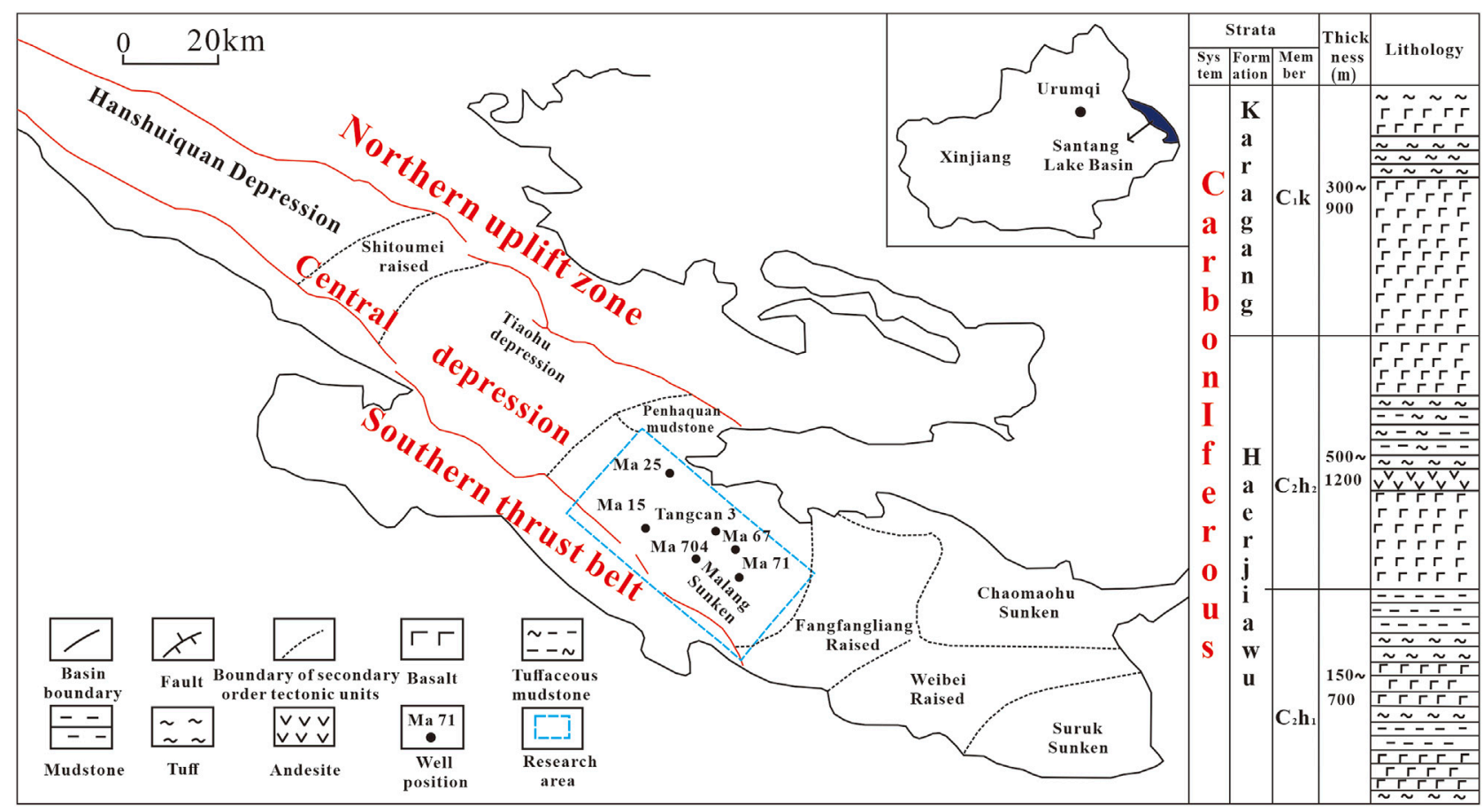

FIGURE 1 | Location of the study area in the Santanghu Basin.

detection range of pore size was $0.4-200 \mathrm{~nm}$ in the tests. CRMI tests were performed using an ASPE-730 constant-rate porosimeter. In detail, liquid mercury was injected into the samples at a low constant velocity, and the information on pore structure can be reflected by the mercury injection pressure. The temperature and relative humidity of the measurement environment were $25^{\circ} \mathrm{C}$ and $34-48 \%$, respectively, in the tests. HPMI tests were conducted using an AutoPore IV 9505 mercury porosimeter. During the test, the samples were first processed, liquid mercury was then injected into the samples, and afterward, pores were detected under a high-pressure condition. The temperature and relative humidity of the measurement environment were $21.3-21.5^{\circ} \mathrm{C}$ and $40-44 \%$, respectively. Meanwhile, the maximum mercury injection pressure was $200 \mathrm{MPa}$, which corresponded to the minimum pore throat size of $3.68 \mathrm{~nm}$.

\section{RESULT ANALYSIS}

\section{Comparison of Basic Characteristics of Volcanic Reservoirs}

1) Lithology and lithofacies

The volcanic rocks in the Malang Sag have complex and diverse lithology, with volcanic lava, pyroclastic rocks, and transition rocks developing. The lithology of the volcanic rocks in the target layers was determined based on multiple means such as core observation, thin section identification, and logging identification (Dong et al., 2012; Chen et al., 2013a; Chen et al., 2013b; Chen et al., 2018). The Kalagang Formation is a set of extrusive rocks erupting from volcanoes interbedded with the transitional facies sedimentary tuff and volcanic breccia formed during the intermission between volcanic eruptions. Meanwhile, lacustrine volcanic depression deposits have developed in local areas of the formation. The Kalagang Formation is gray and dark gray overall and is in light colors such as brown and dark brown in the eruption discontinuities or regions with weathering crust developing. The lithology of the formation is dominated by basic basalts, followed by andesite, tuff, and volcanic breccia. The volcanic rocks of the Haerjiawu Formation are dominated by dotted central volcanic eruptions, with thick laminated basalt facies, basalt facies interbedded with source rocks, and tuff facies mainly developing, and tuff and mudstones widely distributed in the vertical direction. The formation is mostly grayish-brown and brownish-green. The lithology of the Haerjiawu Formation is also dominated by basic basalts. However, unlike the Kalagang Formation, the basalts in the Haerjiawu Formation are distributed among carbonaceous or tuffaceous mudstones. According to the analyses of geochemical indicators, previous researchers unanimously agreed that the carbonaceous mudstones in the Haerjiawu Formation feature high abundance and favorable types and reach the standard of source rocks. Therefore, the basalts in the Haerjiawu Formation are called "basalts interbedded with source rocks," which denote the interbeds consisting of basalts and source rocks (Figure 2).

In terms of lithofacies distribution, the Kalagang Formation is dominated by thick laminated basalt facies and the facies of tuff interbedded with source rocks, with source rock development 


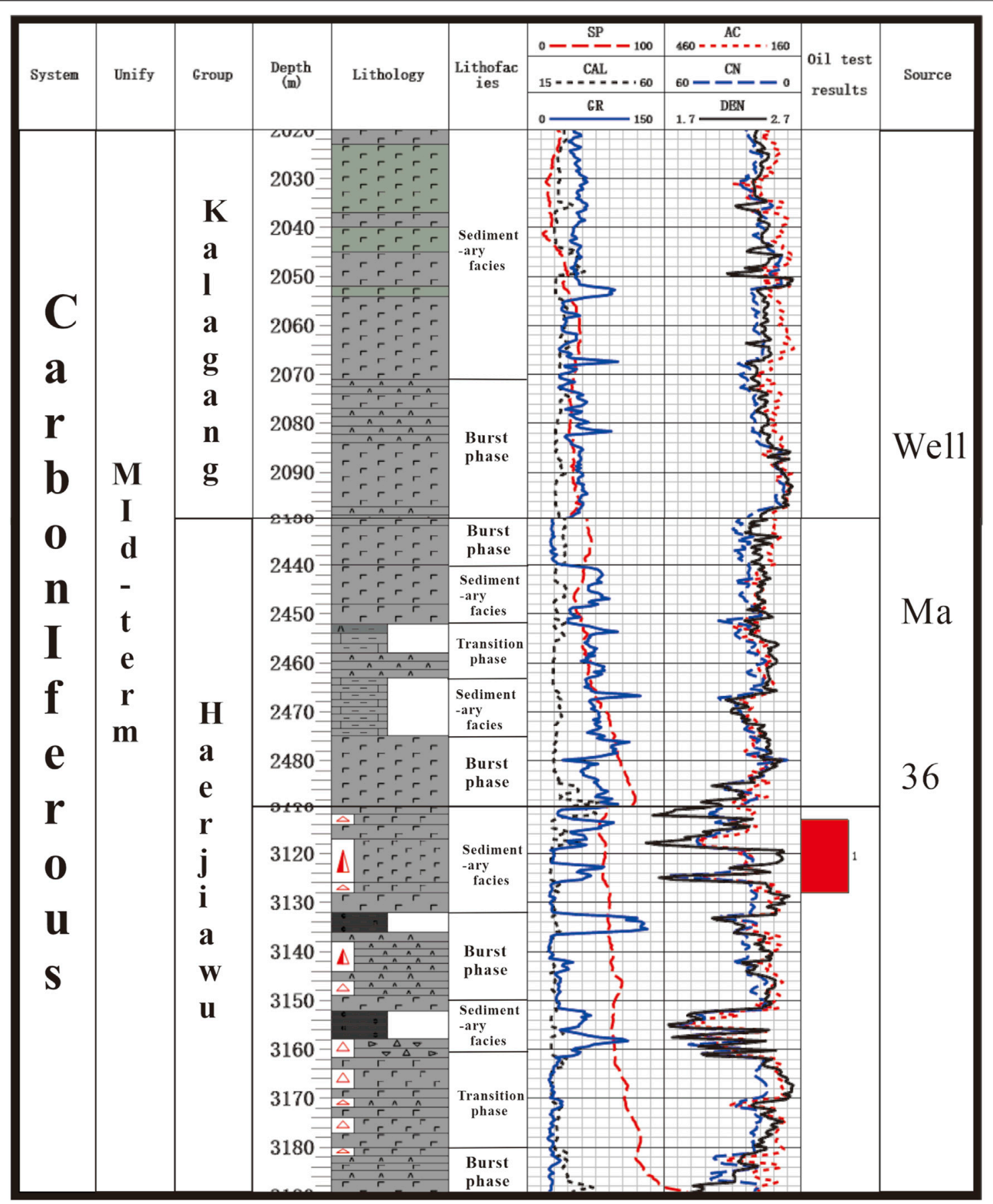

FIGURE 2 | Comprehensive histogram of Carboniferous sedimentary reservoirs in the Malang Sag, Santanghu Basin.

areas locally distributed (Figure 3). Among them, the facies of tuff interbedded with source rocks has mainly developed in blocks of Ma71, Ma73, Ma33, and Ma39 wells, in which the source rocks are more than $80^{\circ} \mathrm{m}$ thick, indicating a shallow lake zone. The thick laminated basalt facies in the Kalagang Formation feature abundantly developed basalts. Furthermore, dense pore or amygdala belts are common at the top of volcanic rocks owing to gas volatilization, with amygdaloidal pores visible and the amygdala mostly filled with chlorites and zeolites. The way of volcanic eruptions is obviously different between the Haerjiawu and Kalagang formations. The Haerjiawu Formation is dominated by dotted central volcanic eruptions, with thick laminated basalt facies, the facies of basalts interbedded with source rocks, and tuff facies primarily developing. The obvious difference between the two formations is that the tuff and mudstones in the Haerjiawu Formation have widely developed 
A

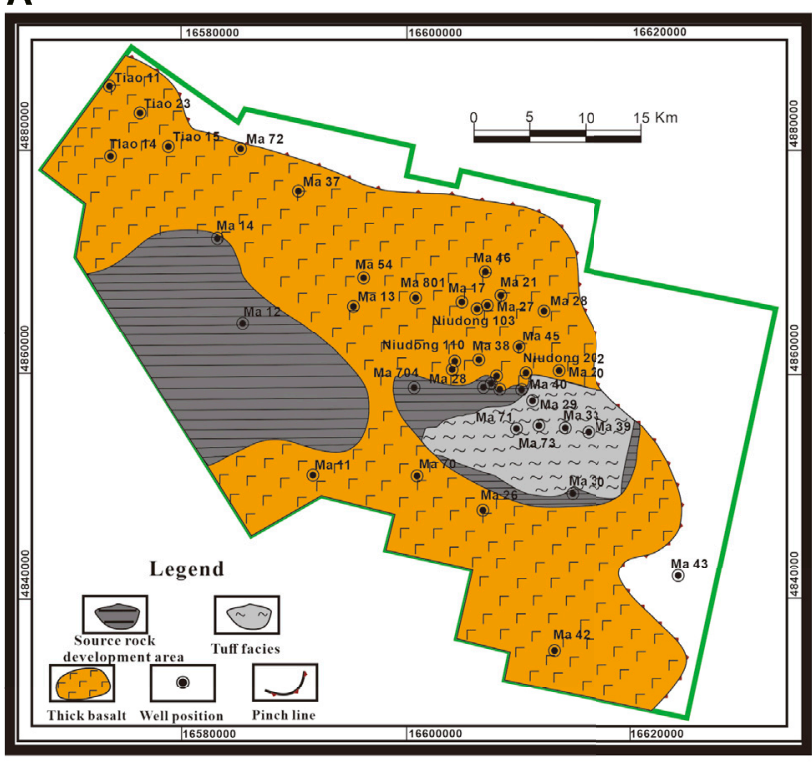

Lithofacies map of the Kalagang Formation
B

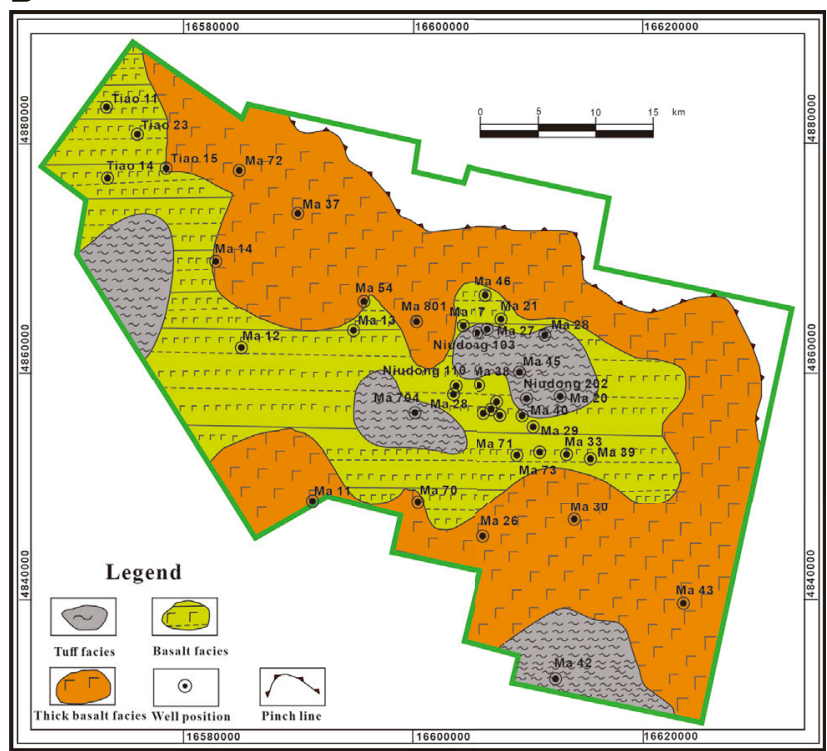

Lithofacies map of the Haerjiawu Formation

FIGURE 3 | Lithofacies maps of Carboniferous sedimentary reservoirs in the Malang Sag, Santanghu Basin. (A) Lithofacies map of the Kalagang Formation. (B) Lithofacies map of the Haerjiawu Formation.

in various vertical depths, indicating that the basalts in the Haerjiawu Formation are deposited underwater. Pores are not fully developed in the Haerjiawu Formation since the water pressure hinders the escape of gas in magma, which affects the physical properties of the formation to a certain extent.

\section{2) Physical characteristics of reservoirs}

The physical properties of reservoirs serve as the direct indicators of pore development and storage capacity of volcanic reservoirs (Pang et al., 2007; Qin, 2011). The analytical results of the porosity and permeability of the samples from the Kalagang and Haerjiawu formations are as follows (Figure 4). For the Kalagang Formation, the maximum and average porosity were 12.78 and $8.31 \%$, respectively, and the maximum and average permeability were $11.15 \times 10^{-3 \circ} \mu^{2}$ and $2.67 \times 10^{-3 \circ} \mu \mathrm{m}^{2}$, respectively. For the Haerjiawu Formation, the maximum and average porosity were 14.07 and $4.46 \%$, respectively, and the maximum and average permeability were $8.04 \times 10^{-3 \circ} \mu \mathrm{m}^{2}$ and $1.12 \times 10^{-3 \circ} \mu^{2}$, respectively. Therefore, the porosity of the Kalagang Formation is notably higher than that of the Haerjiawu Formation (Figures 4C,D), while the permeability of the two formations is slightly different. The microscopic pore structure of reservoirs is composed of pores and pore throats. The pore size affects the porosity, while the pore throat size affects the permeability. Therefore, the results of above analysis indirectly prove that the pores greatly differ, but the pore throats slightly differ between the two formations and that the pore/throat ratio of the Kalagang Formation must be higher than that of the Haerjiawu Formation.

\section{3) Comparison of reservoir space characteristics}

Volcanic reservoirs have various types of storage space and complex pore structures and are strongly affected by secondary diagenism. Pores, joints, and cavities are intertwined in volcanic reservoirs, showing strong heterogeneity both microscopically and macroscopically.

Weathered and leached volcanic reservoirs have developed in the Kalagang Formation, with various types of storage space developing inside the reservoirs, such as corroded pores, pores inside amygdala, residual pores, intercrystalline micropores, contraction joints of amygdala, and tectonic fractures. Among them, the corroded pores, residual pores, and pores inside the amygdala are the most developed, followed by tectonic fractures. Furthermore, the corroded pores are large in scale, with a pore size of up to several hundred microns and above (Figure 5). The basalt reservoirs interbedded with source rocks have developed in the Haerjiawu Formation. The reservoir space inside the reservoirs is dominated by tectonic fractures and corroded micropores, followed by the pores inside amygdala and the contraction joints of amygdala. Moreover, dual media consisting of corroded micropores and tectonic fractures are visible, and a large number of corroded nanopores can be observed under a scanning electron microscope (Figure 6).

Carboniferous basalts have the lowest porosity since they have been filled with magmatic-hydrothermal fluids. Therefore, burialinduced compaction has minor effects on their porosity. The overflow facies, vesicular andesites, and basalts at the top of the Kalagang Formation bear large numbers of contraction pores as a 

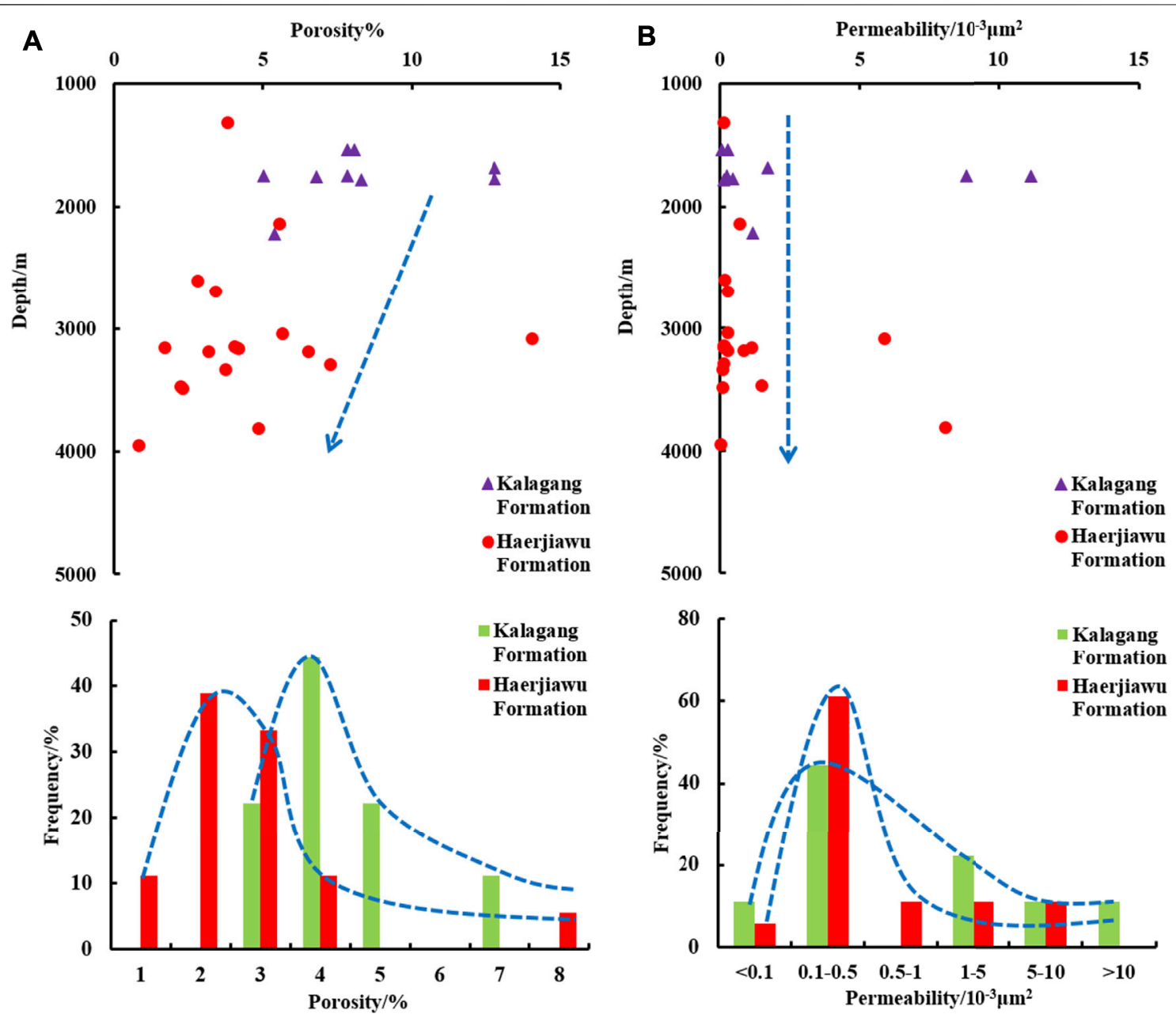

FIGURE 4 | Physical property statistics of Carboniferous reservoirs in the Malang Sag, Santanghu Basin.

result of condensation and shrinkage. Owing to later weathering and leaching, the contraction pores feature large porosity but small pore throats. In contrast, the reservoirs in the Haerjiawu Formation feature improved physical properties since soluble silicates have been corroded by rich organic acids formed from the coal-bearing carbonaceous mudstones in the early stage and the organic acids generated from the maturation of organic matter. Therefore, the combination of small pores and small pore throats in the Haerjiawu Formation is superior to the combination of large pores and small pore throats of the Kalagang Formation.

\section{4) Mineral composition characteristics}

Table 1 shows the whole-rock X-ray diffraction analysis results of the Kalagang and Haerjiawu formations in the Malang Sag. According to the analysis results, the minerals in the two formations are dominated by feldspars, quartz, and zeolites, followed by pyroxenes and carbonate minerals, as well as low content of clay minerals. The two formations notably differ in quartz and heulandite content. In detail, the quartz content of the Kalagang Formation is relatively low, which is generally less than $10 \%$, while the quartz content of the Haerjiawu Formation is relatively high, which is greater than $10 \%$. Meanwhile, the zeolite content of the Kalagang Formation is relatively high, which is higher than $50 \%$ mostly, while the zeolite content of the Haerjiawu Formation is relatively low, which is less than $50 \%$ mostly. Given that quartz has strong weathering resistance and heulandite is liable to dissolve, it can be inferred that the volcanic reservoirs in the Kalagang Formation are more liable to suffer weathering and leaching. As a result, corrosioninduced large pores have been formed. Furthermore, the minerals newly formed after corrosion are liable to block the pore throats, which makes the microscopic pore structures more complicated, increases the tortuosity of the pore-throat system, and contributes to the formation of highporosity and low-permeability reservoirs. This conclusion is not in contradiction to the comparison results of the physical properties of the two formations. Instead, it is consistent with 


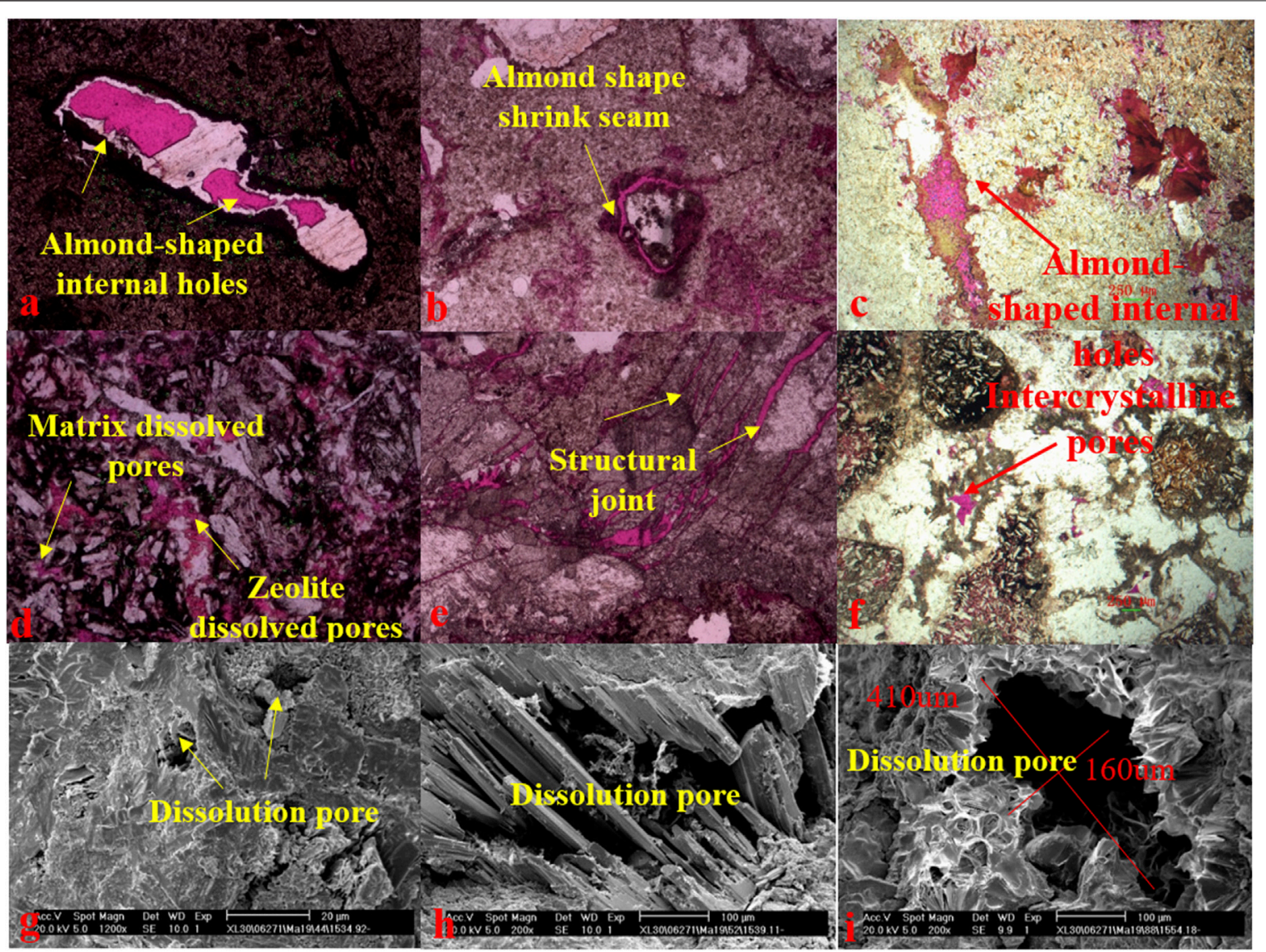

FIGURE 5 | Reservoir space types of weathered and leached volcanic reservoirs in the Kalagang Formation. Note: (A) Well Ma 38, 1,523.7 m deep, altered amygdaloidal andesite and basalts, with pores inside amygdala visible; (B) Well Ma 38, 1,684.61 m deep, clastic altered amygdaloidal basalts, with contraction joints of amygdala visible; (C) Well Niudong110, 1769.77-1769.9 m deep, altered amygdaloidal andesitic basalts, with pores inside amygdala visible; (D) Well Ma 19, 1,559 m deep, andesite, with zeolite dissolved pores and matrix dissolved pores filled with amygdala visible; (E) Well Ma 38, 1,684.61 m deep, clastic altered amygdaloidal basalts, with tectonic fractures visible; (F) Well Niudong110, 1776.32-1776.5 m deep, altered and brecciated clastic amygdaloidal basalts, with intercrystalline pores visible; (G) Well Ma 19, 1,535.015 m deep, grayish-green fluorescent andesite, with dissolved pores visible; (H) Well Ma 19, 1,539.24 m deep, grayish-green andesite bearing oil spots, with intragranular dissolved pores visible; (I) Well Ma 19, 1,554.23 m deep, grayish-green andesite bearing oil traces, with intragranular dissolved pores visible.

the discovery of weathered and leached reservoirs in the Kalagang Formation during practical exploration.

\section{Comparison of Microscopic Pore Structures of Volcanic Rocks}

1) Characteristics of capillary pressure curves

The morphology of capillary pressure curves can reflect the development of microscopic pores in reservoirs. However, owing to extremely strong heterogeneity, the capillary pressure curves have greatly different characteristics at different structural positions of even the same horizon in the volcanic reservoirs. Nearly 20 samples from the Kalagang and Haerjiawu formations were selected for the HPMI test and analysis in this study. Given the heterogeneity of the volcanic reservoir plane and to make a representative comparison of longitudinal microscopic pore structures, this article only exhibits three samples of the same lithology (basalts) at different depths (A, B, and C) of the same well (Well Niudong 110). Among them, samples A and B were collected from the Kalagang Formation and sample $\mathrm{C}$ was taken from the Haerjiawu Formation. In terms of curve morphology (Figure 7), the mercury injection curves become increasingly gentle with an increase in depth, indicating that the pores are better sorted as depth increases. In terms of mercury injection and mercury ejection efficiency, the maximum mercury saturation and mercury ejection efficiency increased as depth increased, although the porosity decreased with an increase in depth. In detail, the maximum mercury saturation increased from 87.795 to $96.228 \%$, and the mercury ejection efficiency increased from 24.256 to $37.789 \%$. In terms of the structure coefficient (Figure 8), the structure coefficient gradually decreased with an increase in depth, indicating that the pore-throat system of the Haerjiawu Formation has small tortuosity and favorable pore throat structures. As indicated by the comparison of the three microscopic parameters, the volcanic rocks in the Haerjiawu 


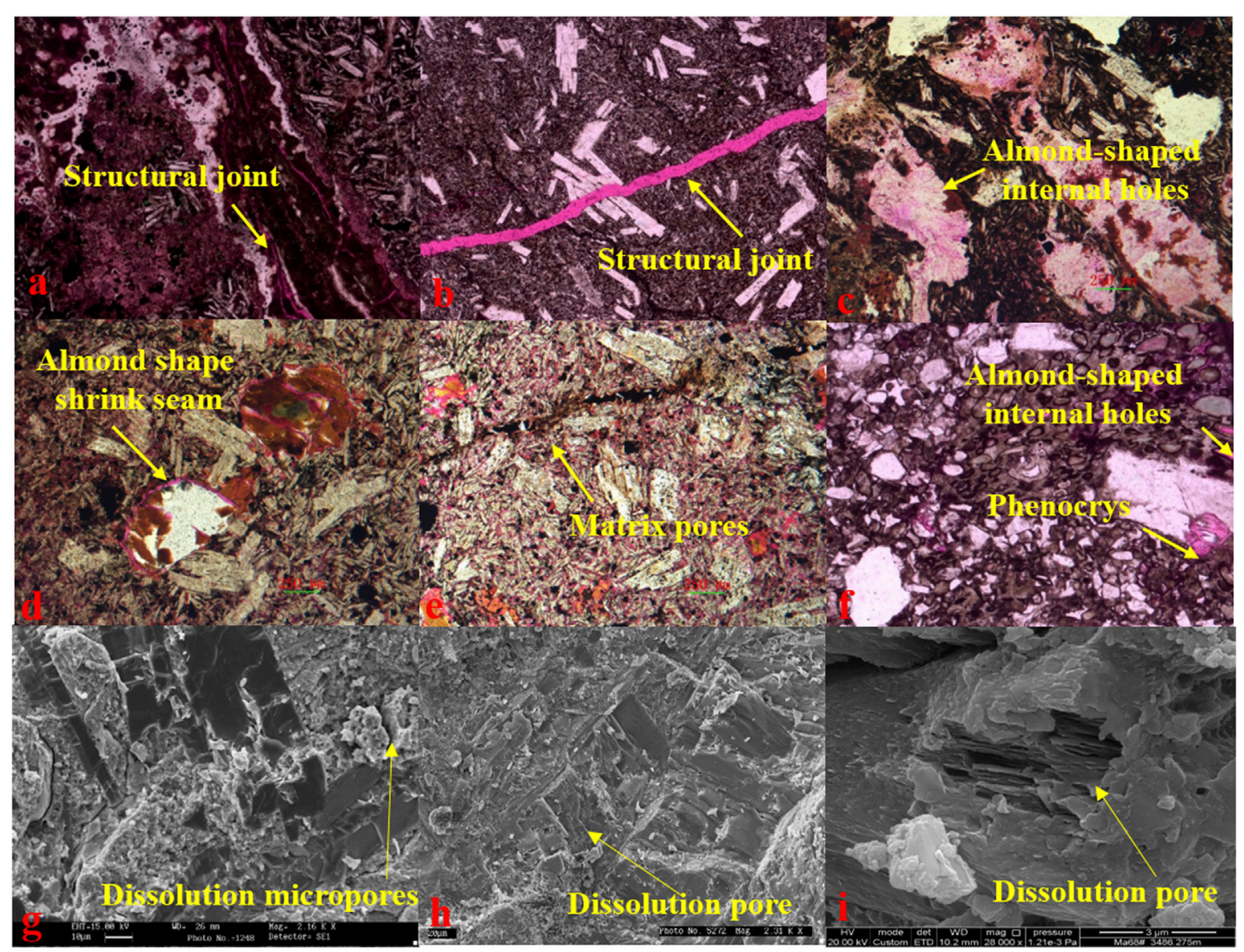

FIGURE 6|Reservoir space types of basalt reservoirs in the Haerjiawu Formation. Note: (A) Well Niudong 201, 3,172.255 m deep, brecciated clastic basalts, with tectonic fractures visible; (B) Well Niudong 201, 3,141.835 m deep, slightly clastic basalts, with tectonic fractures visible; (C)- Well Ma67H, 2,969.53-2,696.71 m, slaglike basalts, with pores inside amygdala visible; (D) Well Ma67H, 2,562.78-2,562.97 m deep, (altered) amygdaloidal basalts, with contraction joints of amygdala visible; (E) Well Ma67H, 2,562.78-2,562.97 m deep, (altered) amygdaloidal basalts, with matrix micropores visible; (F) Well Ma361, 3,161.665 m deep, basaltic crystal lithic fine-grained tuff, with pores inside the amygdala in basaltic breccias, phenocryst dissolved pores inside breccias, and intragranular fractures visible; (G) Well Niudong 201, 3,172.255 m deep, basaltic crystal basalts, with mixed layers consisting of illite and montmorillonite and dissolved micropores visible; (H) Well Ma68, 3,483.945 m deep, grayish-green fluorescent basalts, with feldspar dissolved pores visible; (I)- Well Ma68, 3,486.275 m deep, grayish-green fluorescent basalts, with dissolved pores visible.

Formation pores are well sorted, despite their poor physical properties, which is more conducive to fluid flow.

\section{2) Characteristics of LTNA curves}

Nitrogen isothermal adsorption at a low temperature and low pressure can be used to effectively reflect the pore size distribution of micropores and mesopores in rock samples. Furthermore, the specific surface area can be calculated using the BET equation, the pore volume distribution can be calculated using the $\mathrm{BJH}$ equation, and the pore shapes can be predicted according to the isothermal adsorption curves (Yang et al., 2013b; Yang et al., 2013c).

The distribution curves of pore volume increments-pore sizes of the 17 samples-were plotted using the parameters of microscopic pore structures obtained from the LTNA tests (Figure 9). According to Figure 9, the volcanic reservoirs of the Kalagang and Haerjiawu formations show roughly similar pore size distribution curves, with peaks basically occurring in the range of $30-100 \mathrm{~nm}$. However, the pore volume increments corresponding to pore sizes are different. The weathered and leached volcanic reservoirs of the Kalagang Formation are relatively dispersed and show relatively high pore volume increments, indicating a wide distribution range of pore sizes. In contrast, the basalt volcanic reservoirs in the Haerjiawu Formation show relatively low pore volume increments and small but more concentrated pore size distribution. Once again as indicated by the above analytical results, the Kalagang Formation features complicated microscopic configuration of pores and pore throats and a wide pore size distribution range, while the reservoirs in the Haerjiawu Formation feature relatively small pore sizes and high homogeneity.

3) Characteristic of CRMI curves 
TABLE 1 | X-ray diffraction analysis results of the Kalagang and Haerjiawu formations in the Malang Sag.

\begin{tabular}{|c|c|c|c|c|c|c|c|c|c|c|c|c|c|}
\hline Well & $\begin{array}{l}\text { Depth } \\
\text { (m) }\end{array}$ & Formation & $\begin{array}{l}\text { Lithology } \\
\text { description }\end{array}$ & $\begin{array}{l}\text { Quartz } \\
(\%)\end{array}$ & $\begin{array}{l}\text { Feldspar } \\
(\%)\end{array}$ & $\begin{array}{l}\text { Calcite } \\
(\%)\end{array}$ & $\begin{array}{l}\text { Dolomite } \\
\text { (\%) }\end{array}$ & $\begin{array}{l}\text { Siderite } \\
(\%)\end{array}$ & $\begin{array}{l}\text { Pyrite } \\
(\%)\end{array}$ & $\begin{array}{l}\text { Laumontite } \\
\quad(\%)\end{array}$ & $\begin{array}{l}\text { Heulandite } \\
(\%)\end{array}$ & $\begin{array}{l}\text { Pyroxene } \\
(\%)\end{array}$ & $\begin{array}{c}\text { Clay } \\
\text { minerals } \\
(\%)\end{array}$ \\
\hline $\begin{array}{l}\text { Well } \\
\text { Niudong } 110\end{array}$ & 1748.925 & $\mathrm{C}_{2} \mathrm{k}$ & Grayish-green fluorescent basalt & 3.7 & 83.3 & 2.7 & - & - & - & - & - & 3.7 & 6.5 \\
\hline $\begin{array}{l}\text { Well } \\
\text { Niudong } 110\end{array}$ & 1781.58 & $\mathrm{C}_{2} \mathrm{k}$ & Gray oil trace-bearing basalts & 1.2 & 53.6 & 18.2 & 1.4 & - & - & - & 6.1 & 15.8 & 3.6 \\
\hline Well Ma 38 & $1,684.77$ & $\mathrm{C}_{2} \mathrm{k}$ & Gray oil spotted basalts & 7.1 & 12.2 & - & 1.2 & 1.1 & 1.6 & - & 49.3 & 9.2 & 18.3 \\
\hline Well Ma 38 & 1775.155 & $\mathrm{C}_{2} \mathrm{k}$ & Gray oil trace-bearing andesite & 1.1 & 18.4 & - & - & - & - & - & 70.2 & 5.5 & 4.8 \\
\hline Well Ma 25 & $2,217.915$ & $\mathrm{C}_{2} \mathrm{k}$ & Gray oil trace-bearing basalts & 9.8 & 64.2 & - & 2.4 & - & - & - & - & 15.5 & 8.1 \\
\hline Well Ma 19 & $1,537.215$ & $\mathrm{C}_{2} \mathrm{k}$ & $\begin{array}{l}\text { Grayish-green fluorescent } \\
\text { andesite }\end{array}$ & 0.8 & 27.8 & - & - & 0.5 & 0.7 & - & 54.1 & 7.2 & 7.1 \\
\hline Well Ma 19 & $1,540.53$ & $\mathrm{C}_{2} \mathrm{k}$ & $\begin{array}{l}\text { Grayish-green oil trace-bearing } \\
\text { basalts }\end{array}$ & - & 15.3 & - & - & 1.2 & 1.9 & - & 55.2 & 8 & 18.4 \\
\hline Well Ma $67 \mathrm{H}$ & $3,083.06$ & $\mathrm{C}_{2} \mathrm{~h}$ & Gray fluorescent basalt & 2.3 & 13.2 & 1.9 & 1.7 & 0.6 & 1 & 54.9 & 10.2 & 4.8 & 5.7 \\
\hline $\begin{array}{l}\text { Well } \\
\text { Niudong } 201\end{array}$ & $3,143.985$ & $\mathrm{C}_{2} \mathrm{~h}$ & Gray oil trace-bearing basalts & 5.3 & 26.3 & 2.2 & 2.5 & 1.2 & 1.9 & - & 2 & 16.4 & 4 \\
\hline $\begin{array}{l}\text { Well } \\
\text { Niudong } 201\end{array}$ & $3,151.345$ & $\mathrm{C}_{2} \mathrm{~h}$ & Dark gray fluorescent basalts & 5.9 & 53.3 & 7 & 2 & 1.7 & 2.6 & - & 5.1 & 18.4 & 4.1 \\
\hline $\begin{array}{l}\text { Well } \\
\text { Niudong } 201\end{array}$ & $3,155.82$ & $\mathrm{C}_{2} \mathrm{~h}$ & Gray oil trace-bearing basalts & 19 & 32 & 5.8 & - & 1 & 1.5 & 15.5 & 10.6 & 6.4 & 8.3 \\
\hline $\begin{array}{l}\text { Well } \\
\text { Niudong } 201\end{array}$ & $3,162.875$ & $\mathrm{C}_{2} \mathrm{~h}$ & Dark gray basalts & 27.7 & 50.7 & 7.3 & - & - & - & - & - & 7.6 & 6.7 \\
\hline $\begin{array}{l}\text { Well } \\
\text { Niudong } 201\end{array}$ & $3,184.74$ & $\mathrm{C}_{2} \mathrm{~h}$ & Dark gray fluorescent andesite & 10.4 & 69.8 & - & 0.6 & 1.1 & 1.7 & - & - & 11.6 & 4.7 \\
\hline Well Ma 704 & $3,470.865$ & $\mathrm{C}_{2} \mathrm{~h}$ & Gray fluorescent basalt & 14.8 & 50.8 & 2.2 & - & - & - & 20.6 & - & - & 11.6 \\
\hline $\begin{array}{l}\text { Well } \\
\text { Niudong } 110\end{array}$ & $2,599.525$ & $\mathrm{C}_{2} \mathrm{~h}$ & Dark gray fluorescent basalts & 2.9 & 62.9 & - & 5.8 & - & - & - & - & 24.9 & 3.4 \\
\hline Well Ma 68 & $3,486.275$ & $\mathrm{C}_{2} \mathrm{~h}$ & Grayish-green fluorescent basalts & 10.4 & 63.5 & 2.3 & - & 1.4 & 2.1 & - & - & 7.1 & 13.3 \\
\hline Well Ma 43 & 1,319.95 & $\mathrm{C}_{2} \mathrm{~h}$ & Brown basalts & - & 51.2 & - & 5.6 & - & - & - & 5.2 & 25.7 & 12.2 \\
\hline Well Ma 26 & $3,811.945$ & $\mathrm{C}_{2} \mathrm{~h}$ & $\begin{array}{l}\text { Grayish-green fluorescent } \\
\text { andesite }\end{array}$ & - & 50.7 & 0.3 & - & - & - & 34.7 & 3.1 & 4.7 & 6.6 \\
\hline Well Ma 25 & $3,336.12$ & $\mathrm{C}_{2} \mathrm{~h}$ & Taupe fluorescent basalts & 6.8 & 42.9 & - & 5.4 & - & - & 14.3 & 2.8 & 15.1 & 12.7 \\
\hline Well Ma 20 & $2,141.875$ & $\mathrm{C}_{2} \mathrm{~h}$ & Gray basalts & 27.9 & 43.9 & 6.3 & - & - & - & - & 3.5 & 4.4 & 14.1 \\
\hline
\end{tabular}




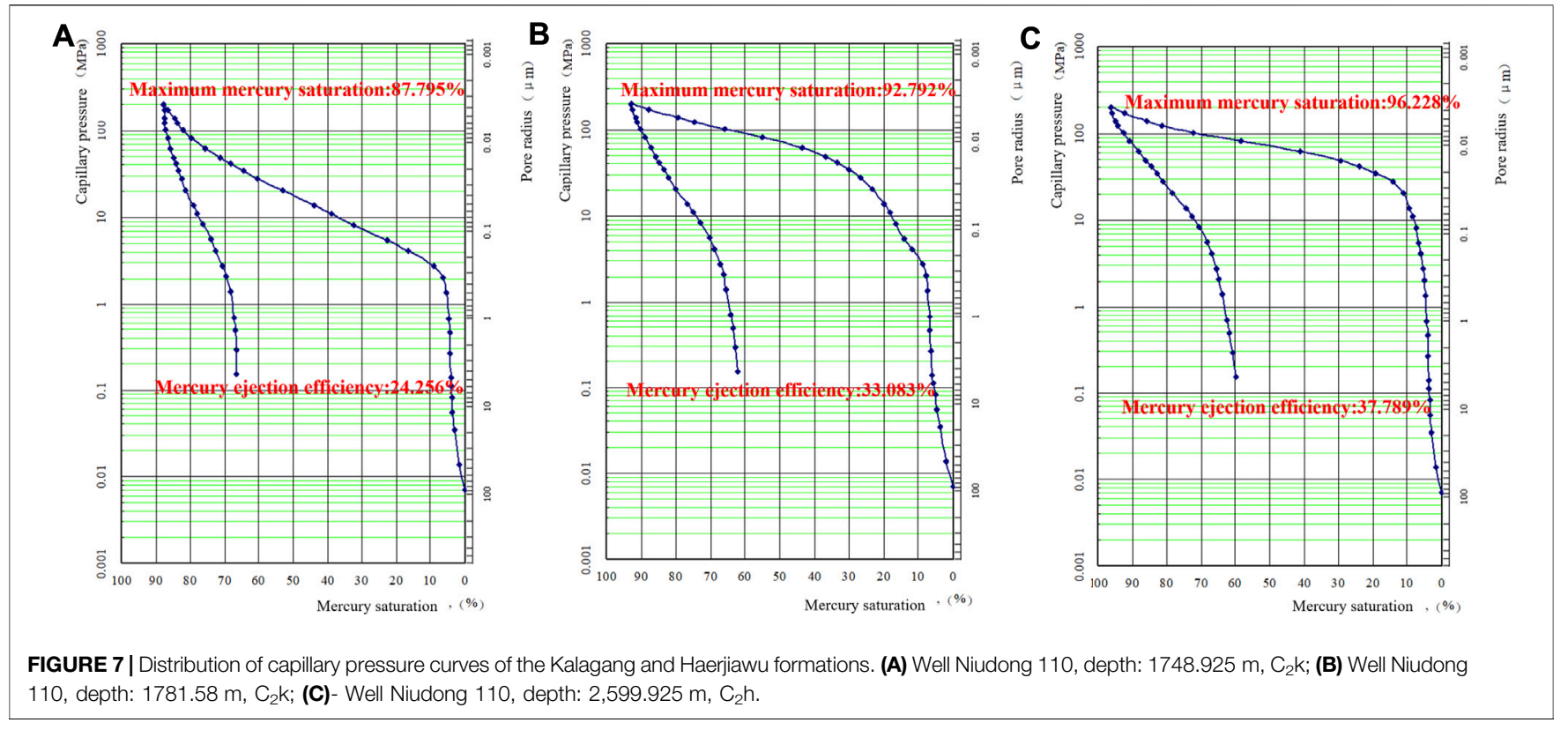

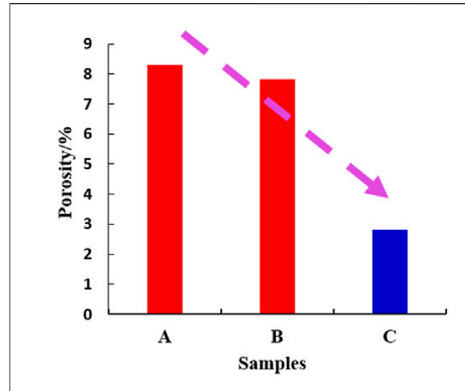

Porosity

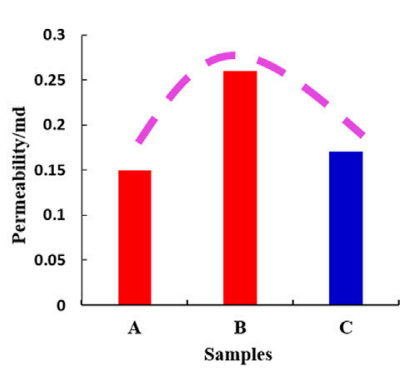

Permeability

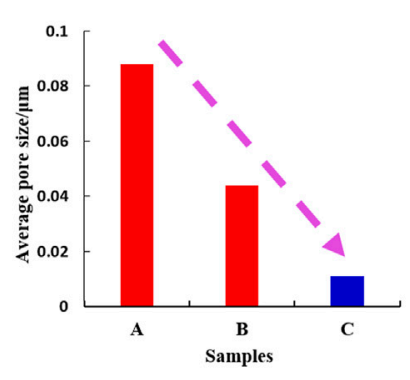

Average pore size

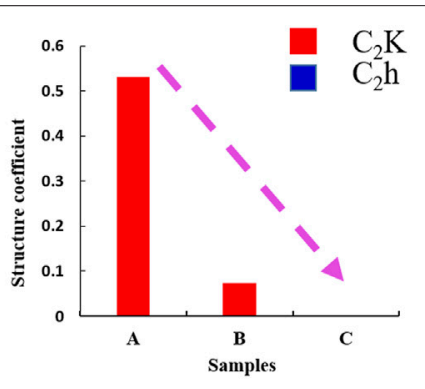

Structure coefficient

FIGURE 8 | Comparison of micro-parameters of the Kalagang and Haerjiawu formations. (A) Well Niudong 110, depth: 1748.925 m, $\mathrm{C}_{2} \mathrm{k}$; (B) Well Niudong 110 , depth: $1781.58 \mathrm{~m}, \mathrm{C}_{2} \mathrm{k}$; (C) Well Niudong 110, depth: 2,599.925 m, $\mathrm{C}_{2} \mathrm{~h}$.
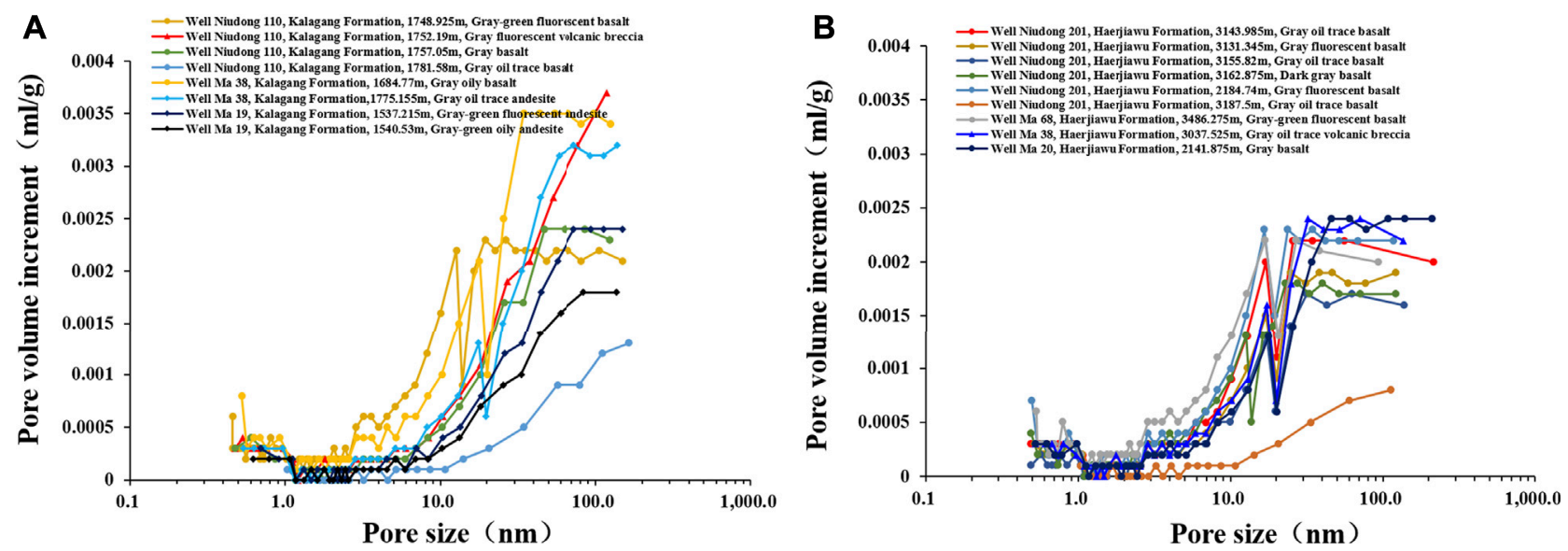

FIGURE 9 |Distribution of pore volume increments - pore size of nanopores - in the volcanic reservoir of the Santanghu Basin. (A) Weathered crust basalts in the Kalagang Formation; (B) Basalts interbedded with source rocks in the Haerjiawu Formation. 


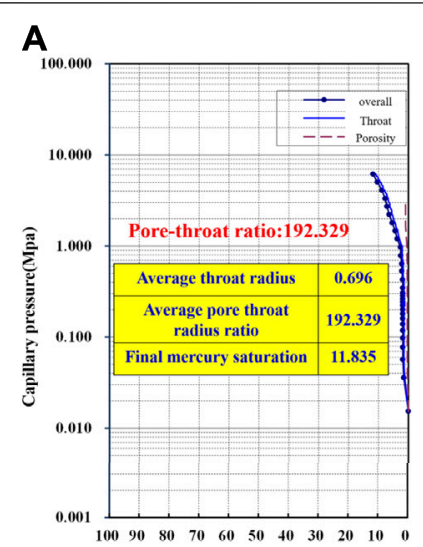

Mercury saturation(\%)

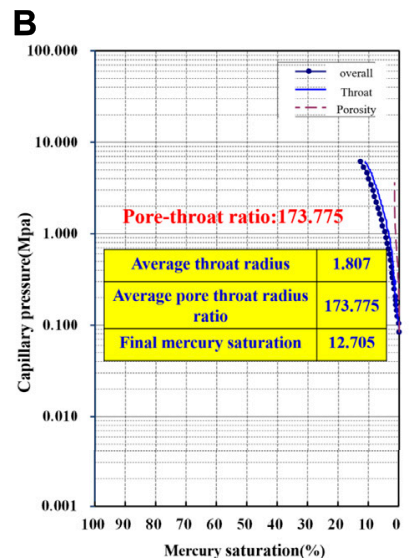

Mercury saturation(\%)
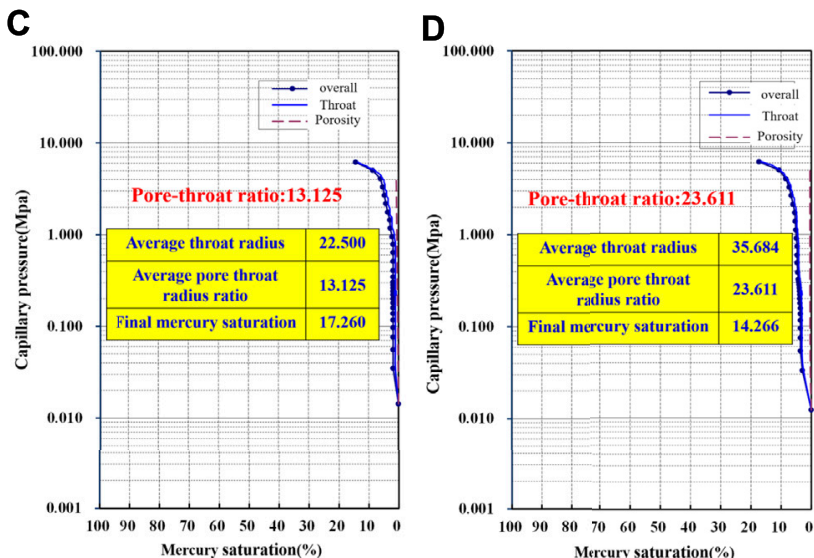

FIGURE 10 | CRMl curves of the Kalagang and Haerjiawu Formations in the Santanghu Basin. (A) Well Ma 19, depth: 1,537.215 m, C 2 k; (B) Well Ma 38, depth: 1775.155 m, $\mathrm{C}_{2} \mathrm{k}$; (C) Well Ma 38, depth: 3,037.525 m, $\mathrm{C}_{2} \mathrm{~h}$; (D) Well Niudong 201, depth: 3,143.985 m, $\mathrm{C}_{2} \mathrm{~h}$.

CRMI is a high-precision technique used to characterize pore-throat structures. Different from conventional HPMI tests, CRMI is to inject mercury into the throat and pores in rocks at a very low quasi-static constant rate $\left(5 \times 10^{-5} \mathrm{ml} / \mathrm{min}\right)$ and then to determine the microscopic pore structure according to the natural pressure fluctuation occurring when the meniscus of mercury front passes through different microscopic pore shapes (Igathinathane et al., 2008; Shan et al., 2019). It possesses the technical advantage that it can distinguish the pore throats from the pores and thus can determine pore sizes and pore throat size separately.

Four samples from the Kalagang and Haerjiawu formations were selected for the CRMI tests. According to Figure 10, the morphology of the total mercury saturation curves roughly approximates to that of the throat mercury saturation curves. The volume of mercury injected into pores was low, with the maximum pore mercury saturation of lower than $20 \%$ generally, indicating that the pores in the samples from the study area are undeveloped overall. Different samples showed slightly different pore size distribution but significantly different pore throat sizes and pore/throat ratios. In detail, the pore throat sizes of the Kalagang Formation were 0.696 and 1.807, while those of the Haerjiawu Formation were 22.5 and 35.684. Meanwhile, the pore/ throat ratios of the Kalagang Formation were 192.329 and 173.775, while those of the Haerjiawu Formation were 13.125 and 23.611. This intuitively indicates that the Haerjiawu Formation has larger throat sizes, lower pore/throat ratios, and high uniformity of pores and pore throats than the Kalagang Formation.

\section{DISCUSSION}

According to the systematic comparison of the lithology, lithofacies, physical properties, reservoir space, mineral constituents, and microscopic pore structures between the Kalagang and Haeriawu formations (Table 2), the reservoirs in the two formations notably differ in porosity, permeability, the configuration of pores and pore throats, mineral constituents, and reservoir space. The differences in lithology and lithofacies are that the basalts in the Haerjiawu Formation are interbedded with carbonaceous mudstones-a type of source rocks. In terms of physical properties, the two formations show similar permeability, even though the Haerjiawu Formation has low porosity. In terms of reservoir space, the Kalagang Formation is dominated by large-scale weathered and leached pores, while the Haerjiawu Formation is dominated by small-scale corroded micropores. In terms of mineral constituents, heulandites conducive to the formation of weathered corroded pores have developed in the Kalagang Formation, while quartz conducive to the formation of fractures have developed in the Haerjiawu Formation. According to the comparison of HPMI tests, the Kalagang Formation has low maximum mercury saturation, low mercury ejection efficiency, and high pore structure tortuosity, while the Haerjiawu Formation has high maximum mercury saturation, high mercury ejection efficiency, and low pore structure tortuosity despite low porosity. The LTNA tests show that the Kalagang Formation features a wide distribution range of nanopore sizes, while the Haerjiawu Formation has a relatively concentrated distribution range of pore sizes. Meanwhile, CRMI tests indicate that the pore/throat ratio of the Kalagang Formation is significantly higher than that of the Haeriawu Formation. According to the comparison of the above various geological characteristics (whether the comparison of lithologic associations and pore morphology or the quantitative comparison of microscopic pores), the volcanic rocks of the Kalagang Formation have the microscopic pore structure of large pores and small pore throats compared with those of the Haeriawu Formation. The geological reason is that the volcanic rocks in the two formations were formed in different geological environments. The Kalagang Formation is of thick laminated basalt facies, with large numbers of basalts developing. Furthermore, dense pore or amygdala belts are common at the top of the formation owing to gas volatilization, with amygdaloidal pores visible and amygdala mostly filled with chlorites and zeolites, indicating notable weathering and leaching. In contrast, the basalts in the Haerjiawu Formation are in a multistage eruption pattern. The volcanic activities weakened in the later stage. As a result, 
TABLE 2 | Comparison of microscopic characteristics of Carboniferous volcanic reservoirs in the Malang Sag, Santanghu Basin.

\begin{tabular}{|c|c|c|c|c|}
\hline $\begin{array}{l}\text { Serial } \\
\text { number }\end{array}$ & Parameter & Kalagang Formation & Haerjiawu Formation & Supporting data \\
\hline 1 & Lithology & Basalt & Basalt & Lithology section (Figure 2) \\
\hline 2 & Lithofacies & $\begin{array}{l}\text { Thick laminated basalt facies } \\
\text { formed from the volcanic rock } \\
\text { eruptions above water }\end{array}$ & $\begin{array}{l}\text { Basalts interbedded with source rocks formed } \\
\text { from underwater eruptions of the volcanic } \\
\text { rocks }\end{array}$ & Lithography (Figure 3) \\
\hline 3 & Mineral constituents & $\begin{array}{l}\text { Low content of quartz and high } \\
\text { content of zeolite }\end{array}$ & $\begin{array}{l}\text { High content of quartz and low content of } \\
\text { zeolite }\end{array}$ & X-ray diffraction analysis (Table 1) \\
\hline 4 & Reservoir space & $\begin{array}{l}\text { Corroded pores, gas pores, and } \\
\text { pores inside amygdala }\end{array}$ & $\begin{array}{l}\text { Corroded pores (joints), tectonic fractures, } \\
\text { contraction joints of amygdala, pores inside } \\
\text { amygdala, intercrystalline pores of zeolites, } \\
\text { and matrix micropores }\end{array}$ & $\begin{array}{l}\text { Observation of cast thin sections (Figure } 9 \\
\text { and Figure 10) }\end{array}$ \\
\hline 5 & Porosity & High & Low & Physical property analysis (Figure 4) \\
\hline 6 & Permeability & Similar & Similar & Physical property analysis (Figure 4) \\
\hline 7 & $\begin{array}{l}\text { Configuration of pores } \\
\text { and pore throats }\end{array}$ & $\begin{array}{l}\text { Pores connecting small pore } \\
\text { throats }\end{array}$ & Pores connecting large pore throats & HPMI and CRMI analysis (Figure 5-Figure 8) \\
\hline 8 & Pore/throat ratio & $>150$ & $<30$ & CRMI analysis (Figure 8) \\
\hline 9 & Schematic diagram & $\begin{array}{l}\text { Large difference between a pore } \\
\text { and a pore throat }\end{array}$ & $\begin{array}{l}\text { Small differences between a pore and a pore } \\
\text { throat }\end{array}$ & Comprehensive test analysis \\
\hline 10 & $\begin{array}{l}\text { Favorable conditions } \\
\text { for tight oil } \\
\text { accumulation }\end{array}$ & Far from provenance, low mobility & Near to provenance and high mobility & $\begin{array}{l}\text { Exploration facts of self-jetting oil flow in the } \\
\text { volcanic rocks of the Haerjiawu Formation in } \\
\text { wells Ma } 67 \text { and Ma } 36\end{array}$ \\
\hline
\end{tabular}

volcanic explosions failed to occur due to insufficient eruption power, and the energy of the volcanic activities was released in the form of relatively gentle overflow (i.e., underwater eruptions of volcanic rocks). Furthermore, the Haerjiawu Formation features a special lithologic association-interbeds consisting of basalts and source rocks, and the organic acids generated during the evolution of the source rocks promoted the corrosion of the reservoirs. All these not only open the channels for oil and gas charging but also provide the oil and gas occurrence space.

\section{CONCLUSION}

1) The volcanic rocks of the Kalagang and Haerjiawu formations are similar in lithology and are both dominated by basalts. However, their formation environments are notably different. The Kalagang Formation is of thick laminated basalt facies formed from volcanic rock eruptions above water, while the Haerjiawu Formation is of basalt interbed facies formed from underwater volcanic eruptions. Furthermore, the Kalagang Formation has relatively high porosity and high zeolite content, with large-scale corroded pores and pores inside amygdala developing. In contrast, the Haerjiawu Formation has relatively low porosity and permeability and low zeolite content, with corroded pores and tectonic fractures developing.

2) The volcanic reservoirs in the Kalagang and Haerjiawu formations have notably different microscopic characteristics. Although nanopores and micropores have developed in the reservoirs of both the formations, the volcanic rocks in the Kalagang Formation have more complex microscopic pore structures and a larger distribution range of pore sizes, while the volcanic rocks of the Haerjiawu Formation have more homogeneous microscopic pores and concentrated pore size distribution. Moreover, in terms of the configuration of pores and pore throats, large pores connect small pore throats in the Kalagang Formation, while small pores connect large pore throats in the Haerjiawu Formation.

3) Tight reservoirs should not be assessed only using physical properties (porosity and permeability) as direct indicators. A systematic assessment of microscopic pore structures should be performed based on microscopic experiments. In particular, it should be noted that it is the pore-throat configuration that serves as the key parameter determining reservoir quality.

\section{DATA AVAILABILITY STATEMENT}

The original contributions presented in the study are included in the article/supplementary material; further inquiries can be directed to the corresponding author.

\section{AUTHOR CONTRIBUTIONS}

All authors listed have made a substantial, direct, and intellectual contribution to the work and approved it for publication.

\section{ACKNOWLEDGMENTS}

This study was supported by grants from the Natural Science Foundation of China (No. 41672125) and the Natural Science Foundation of Shandong Province (ZR2020MD027). We thank Mr. Li Jie from Petroleum Exploration and Production Research Institute of CNPC Tuha Oil Company for their help in sample and data gathering for this study. 


\section{REFERENCES}

Chen, C., Huang, Z., and Chen, X. (2018). The Formation Conditions of the Upper Carboniferous Near-Source Tuff Tight Oil Reservoir Santanghu Basin, Xinjiang Province. Geol. Bull. China 37 (1), 83-92. doi:10.3969/j.issn.1671-2552.2018.01.009

Chen, H., Jiang, P., and Zhang, D. (2013). Classification and Distribution Evaluation of Pore Structure of Volcanic Reservoirs: Taking the Volcanic Reservoirs of the First Member of Yingcheng Formation in Xudong Area of Songliao Basin as an Example [J]. J. Cent. South Univ. (Natural Sci. Edition) 44 (04), 1453-1463.

Chen, L., Lu, Y., Jiang, S., Li, J., Guo, T., and Luo, C. (2015). Heterogeneity of the Lower Silurian Longmaxi marine Shale in the Southeast Sichuan Basin of China. Mar. Pet. Geology. 65, 232-246. doi:10.1016/j.marpetgeo.2015.04.003

Chen, W., Xueqiang, S., and Zhi, F. (2013). Diagenesis of Volcanic Reservoir of Karagang Formation in Santang Lake Basin [J]. J. Southwest Pet. Univ. (Natural Sci. Edition) 35 (04), 35-42. doi:10.3863/j.issn.1674-5086.2013.04.005

Dong, G., Zhang, Q., and Zhu, X. (2012). Current Status and Problems of Volcanic Reservoir Study: an Example from the Lower Per-Mian Volcanic Rocks in KeXia Area of Junggar Basin[J]. Oil \& Gas Geology. 33 (4), 511519. doi:10.11743/ ogg20120403

Hadlari, T. (2015). Oil Migration Driven by Exhumation of the Canol Formation Oil Shale: A New Conceptual Model for the Norman Wells Oil Field, Northwestern Canada. Mar. Pet. Geology. 65, 172-177. doi:10.1016/ j.marpetgeo.2015.03.027

Hou, L., Wang, J., and Zou, C. (2011). Controlling Factors of Volcanic Weathering Reservoirs: Taking the Carboniferous Karagang Formation as an Example [J]. Acta Geologica Sinica 85 (04), 557-568.

Huang, Z., Liu, B., and Luo, Q. (2012). Main Controlling Factors and Models of Hydrocarbon Accumulation in Carboniferous Volcanic Rock Series in Malang Sag, Santang Lake Basin [J]. Acta Geologica Sinica 86 (08), 1210-1216. doi:10.3969/j.issn.0001-5717.2012.08.004

Igathinathane, C., Pordesimo, L. O., and Columbus, E. P. (2008). Shape Identification and Particles Size Distribution from Basic Shape Parameters Using Image. Comput. Electron. Agric. 63 (2), 168-182. doi:10.1016/ j.compag.2008.02.007

JiaChengzao, Z., and Li, J. (2012). Assessment Criteria, Main Types, Basic Features and Resouece Prospects of the Tight Oil in China [J]. Acta Petrolei Sinica 33 (3), 343-350. doi:10.7623/syxb201203001

Li, G., Mao, S., and Chen, F. (2010). Key Controlling Fac-Tors and Exploration Direction of Volcanic Reservoir in Kalagang Formation of Malang Sag in Santanghu Basin[J]. China Pet. Exploration 15 (1), 11-15. doi:10.3969/ j.issn.1672-7703.2010.01.003

Liang, H., Gou, H., and Wang, Z.. (2011), Volcanic Lithology and Lithofacies Characteristics of the Karagang Formation in Malang Sag. Santanghu Basin 29 (06), 1156-1163.

Liu, B., Gao, Y., and Liu, K. (2021), Pore Structure and Adsorption Hysteresis of the Middle Jurassic Xishanyao Shale Formation in the Southern Junggar Basin, Northwest China. Energy Exploration \& Exploitation 39, 761-778. doi:10.1177/ 0144598720985136

Liu, B., Sun, J., and Zhang, Y. (2021), Reservoir Space and Enrichment Model of Shale Oil in the First Member of Cretaceous Qingshankou Formation in the Changling Sag, Southern Songliao Basin, NE China. Pet. Exploration Develop. 48 (3), 608-624. doi:10.1016/j.coal.2017.03.011

Liu, B., Bechtel, A., and Sachsenhofer, R. F. (2017c), Depositional Environment of Oil Shale within the Second Member of Permian Lucaogou Formation in the Santanghu Basin, Northwest China. Int. J. Coal Geology. 175, 10-25. doi:10.11743/ogg20130602

Liu, B., Chi, Y., and Huang, Z. (2013). Permian Hydrocarbon Migration Mechanism and Shale Oil Enrichment Law in Malang Sag, Santang Lake Basin [J]. Oil \& gas Geology. 34 (06), 725-730. doi:10.11743/ogg20130602

Liu, B., Jia, M., and Huang, Z. (2015). Identification and Prediction of Carboniferous Volcanic Rock Source Rocks in Malang Sag, Santang Lake Basin [J]. Pet. Geology. Exp. 37 (04), 452-459. doi:10.11781/sysydz201504452

Ma, S., Luo, J., and Chen, C. (2017). Classification and Evaluation of Micro Pore Structure of Volcanic Reservoirs: A Case Study of the Carboniferous Volcanic
Rocks in the Xiquan Area in the Eastern Junggar Basin [J]. Pet. Geology. Exp. 39 (05), 647-654. doi:10.11781/sysydz201705647

Pang, Y., Zhang, F., and Qiu, H. (2007). Microscopic Pore Structure and Physical Parameter Characteristics of Acid Volcanic Reservoirs [J]. Acta Petrolei Sinica 28 (06), 72-77. doi:10.3321/j.issn:0253-2697.2007.06.014

Qin, Hao. (2011). Research on Volcanic Reservoir Classification Method Based on Micro Pore Structure [J]. J. Oil Gas Technol. 33 (01), 98-102. + 168. doi:10.3969/ j.issn.1000-9752.2011.01.022

Shan, P., Mei, Q., and Zhang, H. (2019). Characteristics of Reservoir Pore Size Distribution Based on Thin Section and Rate-Controlled Mercury Injection and its Differential Mechanisms: An Example of Chang-2 Reservoir of Yanchang Formation in a Block of Ordos Basin [J]. Acta Scientiarum Naturalium Universitatis Pekinensis 55 (5), 907-914. doi:10.13209/j.0479-8023.2019.055

Su, D., Wang, Z., and Yuan, Y. (2020). Weathered Volcanic Reservoir Characteristics and Their Controlling Factorson Permian Fengcheng Formation in Southern Mahu Depression, Junggar Basin[J], Nat. Gas Geosci., 31, 2, 209-219. doi:10.11764/j.issn.1672-1926.2019.10.003

Sun, Z., Jiang, Y., and Ming, Z. (2013). Lithology-lithofacies Model of Carboniferous Volcanic Reservoirs in the Junggar Basin, NW China [J]. J. China Univ. Mining \&Technology 425, 782-789.

Tian, W., Lu, S., Wang, W., Jinbu, L., Zhuang, L., and Jie, L. (2019). Evolution Mechanism of Micronano-Scale Pores in Volcanic Weathering Crust Reservoir in the Kalagang Formation in Santanghu Basin and Their Relationship with Oil-Bearing Property[J]. Oil\& gas Geology. 40 (06), 1281-1294. doi:10.11743/ ogg20190612

Wang, L., Li, W., and Tong, L. (2010). Comparative Analysis of Volcanic Reservoir Development Characteristics and Reservoir Formation Controlling Factors of Onshore and Underwater Eruption: a Case Study of the Carboniferous Volcanic Reservoirs in the Santang Lake Basin [ J]. Scientific Geology. 45 (04), 1088-1097. doi:10.3969/j.issn.05635020.2010 .04 .013

Yang, F., Ning, F., and Kong, D. (2013). Pore Structure of Shales from High Pressure Mercury Injection and Nitrogen Adsorption Method[J]. Nat. Gas Geosci. 24 (3), 450-455. doi:10.3969/j.issn.0563-5020.2010.04.013

Yang, F., Ning, Z., and Zhang, S. (2013). Characterization of Pore Structures in Shales through Nitrogen Adsorption Experiment[J]. Nat. Gas Industry 33 (4), 135-140. doi:10.3787/j.issn.1000-0976.2013.04.025

Yang, H., Wang, D., and Gao, Y. (2019). Neogene Gas Origin and Oil and Gas Differential Enrichment Mechanism in the basin Margin of the Bohai Bay Basin: A Case Study of Eastern Slope in the Yellow River Mouth Depression [J]. Acta Petrolei Sinica 40 (05), 509-518.

Yu, B. S. (2013). Classification and Characterization of Gas Shale Pore System. Earth Sci. Front. 20 (4), 211-220. (in Chinese with English abstract).

Conflict of Interest: Author WW and LW are employed by PetroChina.

The remaining authors declare that the research was conducted in the absence of any commercial or financial relationships that could be construed as a potential conflict of interest.

The handling editor declared a shared affiliation with the authors WW and WL at the time of review.

Publisher's Note: All claims expressed in this article are solely those of the authors and do not necessarily represent those of their affiliated organizations, or those of the publisher, the editors, and the reviewers. Any product that may be evaluated in this article, or claim that may be made by its manufacturer, is not guaranteed or endorsed by the publisher.

Copyright (c) 2021 Wang, La, Fan, Xu, Liu and Lv. This is an open-access article distributed under the terms of the Creative Commons Attribution License (CC BY). The use, distribution or reproduction in other forums is permitted, provided the original author(s) and the copyright owner(s) are credited and that the original publication in this journal is cited, in accordance with accepted academic practice. No use, distribution or reproduction is permitted which does not comply with these terms. 